\title{
Community Dedication by KKN UNS Volunteer in Prevention of Covid-19 in Banyumas Regency
}

\author{
Sorja Koesuma \\ Universitas Sebelas Maret \\ kkncovid95@gmail.com
}

\section{Article History}

accepted 31/08/2020

approved 22/09/2020

published 28/10/2020

\begin{abstract}
A Clean and Healthy Lifestyle is still a little strange in the people of Banyumas Regency, Central Java. In the midst of the Covid-19 pandemic, PHBS is being intensified because it is one of the efforts to prevent the transmission of the Covid-19 virus. Lack of public understanding and awareness of clean and healthy lifestyle causes them to be indifferent to the current situation. This research was conducted with the aim of providing an understanding of Covid-19, providing an overview of community service activities in the midst of the Covid-19 pandemic, learning assistance at home during the Covid-19 pandemic and providing education to be ready to face the new normal era. This article uses a qualitative descriptive research method. The data collection technique used are (1) Participant observation (2) Interview, to find out the situation through informant(s), (3) Documentation. Some of the activities or projects carried out by the volunteers of KKN Covid-19 Response are Socialization of the Importance of PHBS (Clean and Healthy Behaviour), Assistance of Learning Activities during Covid-19, Education of New Normal Era, and The Effort of Stress Management during Pandemic.
\end{abstract}

Keywords: KKN (Community Service Program) Sebelas Maret University, Covid-19 Response Education

\begin{abstract}
Abstrak
Pola Hidup Bersih dan Sehat masih sedikit asing di masyarakat Kabupaten Banyumas Jawa Tengah. Ditengah pandemi Covid-19 ini, PHBS sangat digencarkan karena salah satu bentuk upaya pencegahan penularan virus Covid-19. Kurangnya pemahaman dan kesadaran masyarakat tentang pola hidup bersih dan sehat menyebabkan mereka acuh terhadap keadaan yang sedang terjadi. Penelitian ini dilakukan dengan tujuan untuk memberikan pemahaman tentang Covid-19, memberikan gambaran kegiatan pengabdian masyarakat di tengah pademi Covid-19, pendampingan belajar dirumah selama pandemi Covid-19 dan memberikan edukasi untuk siap mengahadapi era new normal. Artikel ini menggunakan metode penelitian deskriptif kualitatif. Teknik pengumpulan data yang dilakukan adalah : (1) Observasi partisipan (2) Wawancara untuk mengetahui keadaan melalui narasumber, dan (3) Dokumentasi. Beberapa kegiatan atau program kerja yang dilakukan relawan KKN tanggap Covid-19 ini berupa Sosialisasi Pentingnya PHBS (Perilaku Hidup Bersih dan Sehat), Pendampingan Kegiatan Belajar di Tengah Covid-19, Edukasi tentang Era Normal Baru (new normal), dan Upaya Pengelolaan Stress ditengah Pandemi.

Kata kunci: Relawan KKN Universitas Sebelas Maret Surakarta, Edukasi Tanggap Covid-19
\end{abstract}

Social, Humanities, and Education Studies (SHEs): Conference Series p-ISSN 2620-9284 https://jurnal.uns.ac.id/shes 


\section{PENDAHULUAN}

Pada awal tahun 2020 ini dunia dikejutkan dengan teridentifikasinya virus Covid-19 yang merebak di seluruh dunia, tak terkecuali di Indonesia. Wabah ini pertama kali di identifikasi di kota Wuhan, Profinsi Hubei, China pada bulan Desember 2019. Diketahui bahwa wabah tersebut disebabkan oleh sindrom pernafasan akut coronavirus 2 (SARS-COV-2). Pada manusia corona dapat menyebabkan infeksi pernafasan mulai dari flu biasa hingga penyakit yang lebih parah seperti Middle East Respiratory Syndrome (MERS), dan Severe Acute Respiratory Syndrme (SARS). Organisasi Kesehatan Dunia (WHO) telah menetapkan status Covid-19 ini sebagai pandemi global sejak 11 Maret 2020. Di seluruh dunia hingga tanggal 23 Juni 2020, telah terjadi lebih dari 9 Juta kasus Covid-19 dengan rincian sebanyak 475.000 penderita mengalami kematian dan lebih dari 4,5 juta penderita telah pulih. Di Indonesia sendiri pada tanggal 23 Juni 2020 tercatat sebanyak 47.896 kasus dengan penambahan perhari mencapai 1.051 kasus. Terdapat 19.241 kasus yang dinyatakan sembuh, dan sebanyak 2.535 orang dinyatakan meninggal karena virus ini.

Pemerintah Indonesia sendiri sudah mengambil tindakan terkait dengan mewabahnya virus Covid-19 ini, hal ini di perlihatkan dengan penetapan Status Darurat Bencana sejak 29 Februari 2020 sampai 29 Mei 2020. Banyak kebijakan kebijakan yang sudah di terapkan oleh pemerintah setelah penetapan Status Darurat Bencana ini, diantaranya menganjurkan masyarakat untuk beraktifitas di rumah, mulai dari belajar, bekerja hingga beribadah. Selain itu ada juga pembatasan sosial dengan skala besar yang dilakukan di berbagai daerah, serta adanya anjuran untuk tidak berkerumun dan melakukan pembatasan sosial (social distancing). Namun, nampaknya usaha pemerintah tersebut masih dinilai kurang efektif karena usaha tersebut belum didukung oleh kesadaran dan pemahaman masyarakat terkait Covid-19 ini. Pemahaman dan kesadaran masyarakat tentang Covid-19 masih cukup rendah sehingga menyebabkan mereka acuh terhadap keadaan yang sedang terjadi. Hal ini dibuktikan dengan banyaknya kasus yang terjaid seperti di wilayah Purwokerto Timur, Kabupaten Banyumas masih banyak ditemukan orang yang beraktifitas diluar tanpa menggenakan masker, sehingga kurang lebih ada 20 orang perharinya yang terjaring operasi masker. Contoh tersebut menunjukan bahwa masih rendahnya pemahaman masyarakat akan bahaya Covid-19.

Penerapan pola hidup baru pada berbagai aspek kehidupan pun di lakukan sebagai langkah pencegahan penularan virus Covid-19 ini. Banyak kebijakan dan langkah baru yang dibuat seperti adanya kebijakan pembelajaran yang dilakukan melalui sistem jarak jauh dalam jaringan guna mengurangi resiko terjadinya penulara virus selama kegiatan pembelajaran. Berdasarkan penelitian yang dilakukan (Dewi, 2020) dampak Covid-19 ini terhadap implementasi pendidikan khususnya di sekolah dasar sudah dapat dilaukan dengan baik, namun masih banyak hambatan yang timbul ketika pelaksaannya. Terdapat beberapa hambatan yang di alami baik guru, siswa, hingga orang tua. Beberapa dampak yang di rasakan oleh siswa yaitu tidak adanya sarana dan prasarana yang memadahi, tidak hanya itu guru pun memiliki kendala yaitu kurangnya keterampilan menggunakan teknologi, atau media sosial untuk melakukan pembelajaran (Purwanto, 2020).

Dampak Covid-19 ini juga mendorong perguruan tinggi untuk membuat sebuah kebijakan terkait dengan kegiatan-kegiatan yang seharusnya dilakukan walaupun ditengah pandemi Covid-19 ini. Salah satu kegiatan yang harus di lakukan yaitu Pengabdian Kepada Masyarakat berdasarkan pada Tri Darma Perguruan Tinggi poin ketiga, kegiatan ini merupakan perwujudan dari kegiatan pengabdian mahasiswa kepada masyarakat untuk dapat mengamalkan ilmu pengetahuan, teknologi, serta membantu masyarakat memenuhi kebutuhan. Ditengah pandemi Covid-19 ini Universitas Sebelas Maret memberikan kebijakan untuk mahasiswanya tetap melaksanakan point ketiga dalam Tri Darma Perguruan Tinggi ini dengan menyesuaikan keadaaan yang ada. KKN yang dilakukan ini bertemakan KKN Covid-19 Universitas Sebelas Maret. Seperti KKN sebelumnya KKN Covid-19 ini dilakukan dengan tujuan untuk dapat mengabdikan diri kepada masyarakat, membantu masyarakat sebagai bentuk pengamalan ilmu, dan juga usaha untuk membantu masyarakat dalam mengatasi masalah dan memenuhi kebutuhan masyarakat selama masa pandemi Covid-19. Kegiatan ini dilakukan di daerah tempat tinggal masing-masing mahasiswa dan dilakukan dengan menaati protokol kesehatan yang sudah di tentukan sebelumnya.

Berdasarkan penjelasan tersebut, maka peneliti melakukan penelitian dengan judul Kegiatan Pengabdian Masyarakat Relawan KKN UNS Covid-19 sebagai Bentuk Upaya Pencegahan Penyebaran Virus Covid-19 di Tengah Masyarakat Kabupaten Banyumas. 
Penelitian ini dilakukan dengan tujuan untuk membantu masyarakat khususnya di daerah Kabupaten Banyumas untuk dapat memahami terkait pandemi Virus Covid-19, gambaran terkait kegiatan yang dapat dilakukan guna pengabdian masyarakat ditengah pandemi Covid-19 ini, melakukan pendampingan belajar selama pandemi virus Covid-19 dan juga pembelajaran terkait upaya pengelolaan stress yang dapat dilakukan selama pandemi Covid-19.

\section{METODE}

Artikel ini menggunakan metode penelitian deskriptif kualitatif. Dimana artikel menampilkan hasil data apa adanya tanpa manipulasi atau perlakuan lain. Teknik pengumpulan data yang dilakukan adalah: (1) Observasi Partisipan, dimana peneliti berperan langsung sebagai pelaksana dan terlibat langsung dalam kegiatan penelitian, (2). Wawancara untuk mengetahui keadaan melalui narasumber, dan (3). Dokumentasi yang berupa foto kegiatan. Kegiatan yang dikaji dalam upaya tanggap Covid-19 ini berupa sosialisasi pentingnya PHBS (Perilaku Hidup Bersih dan Sehat), Pendampingan Kegiatan Belajar di Tengah Covid-19, Edukasi tentang Era Normal Baru (new normal), dan Upaya Pengelolaan Stress ditengah Pandemi.

\section{HASIL DAN PEMBAHASAN}

Hasil dari kegiatan pengabdian masyarakat ini adalah pengetahuan dan pemahaman masyarakat tentang covid-19, serta gerakan masyarakat dalam kegiatan tanggap Covid-19. Beberapa kegiatan atau program kerja yang dilakukan relawan KKN tanggap Covid-19 ini berupa Sosialisasi Pentingnya PHBS (Perilaku Hidup Bersih dan Sehat), Pendampingan Kegiatan Belajar di Tengah Covid-19, Edukasi tentang Era New Normal, dan Upaya Pengelolaan Stress ditengah Pandemi. Kegiatan pelaksanaan kegiatan KKN berlangsung dari tanggal 15 Mei 2020 - 30 Juni 2020 di beberapa desa di Kabupaten Banyumas.

Berdasarkan observasi partisipan, wawancara, kajian dokumen dan dokumentasi, deskripsi pelaksanaan program kerja relawan KKN Covid-19 di Kabupaten Banyumas sebagai berikut:

\section{Sosialisasi Pentingnya PHBS (Perilaku Hidup Bersih dan Sehat)}

Kegiatan ini merupakan upaya pemberian edukasi terkait pencegahan wabah Covid-19. Kegiatan yang dilakukan antara lain sosialisasi langkah cuci tangan dengan benar, penggunaan dan pembuatan masker kain, dan penggunaan handsanitizer. Kegiatan ini dilakukan oleh Relawan Amalia Firdaus Yanti di Desa Cibangkong, Relawan Atika Rakhma Febryani di Desa Karang Lewas Lor, Relawan Erina Dian F di Desa Karang Salam Kidul, Relawan Dwi Maftuhah di Desa Sibrama, Relawan Izah Mukti di Desa Tanggeran, Lilis Agus di Desa Karangdadap dan Relawan Sanni Fadilla di Desa Karang Pucung semuanya merupakan desa-desa di Kabupaten Banyumas.

Kegiatan yang dilakukan oleh relawan ini melalui beberapa tahapan, mulai dari mencari informasi terkait masker, handsanitizer, dan cuci tangan dengan sabun yang sesuai dengan standar kesehatan sehingga apa yang disampaikan dan diberikan dapat dipertanggung jawabkan. Selanjutnya informasi tersebut dikemas dengan cara yang menarik sehingga masyarakat dapat menerima informasi dengan baik. Informasi dikemas dalam berbagai bentuk ada poster, video edukasi hingga edukasi langsung dengan tetap menerapkan protokol kesehatan yang dianjurkan.

Informasi disebar melalui berbagai cara, ada yang melalui WhatsApp Group, Instagram Relawan, dan juga melalui pamflet atau selebaran yang dibagikan kepada warga sekitar. Kegiatan yang dilakukan ini banyak mendapat respon baik dari warga. Dengan dilaksanakannya kegiatan ini harapannya yaitu warga lebih memahami terkait virus Covid-19 ini dan juga dapat menjaga diri dari penularan Virus Covid-19 ini. 

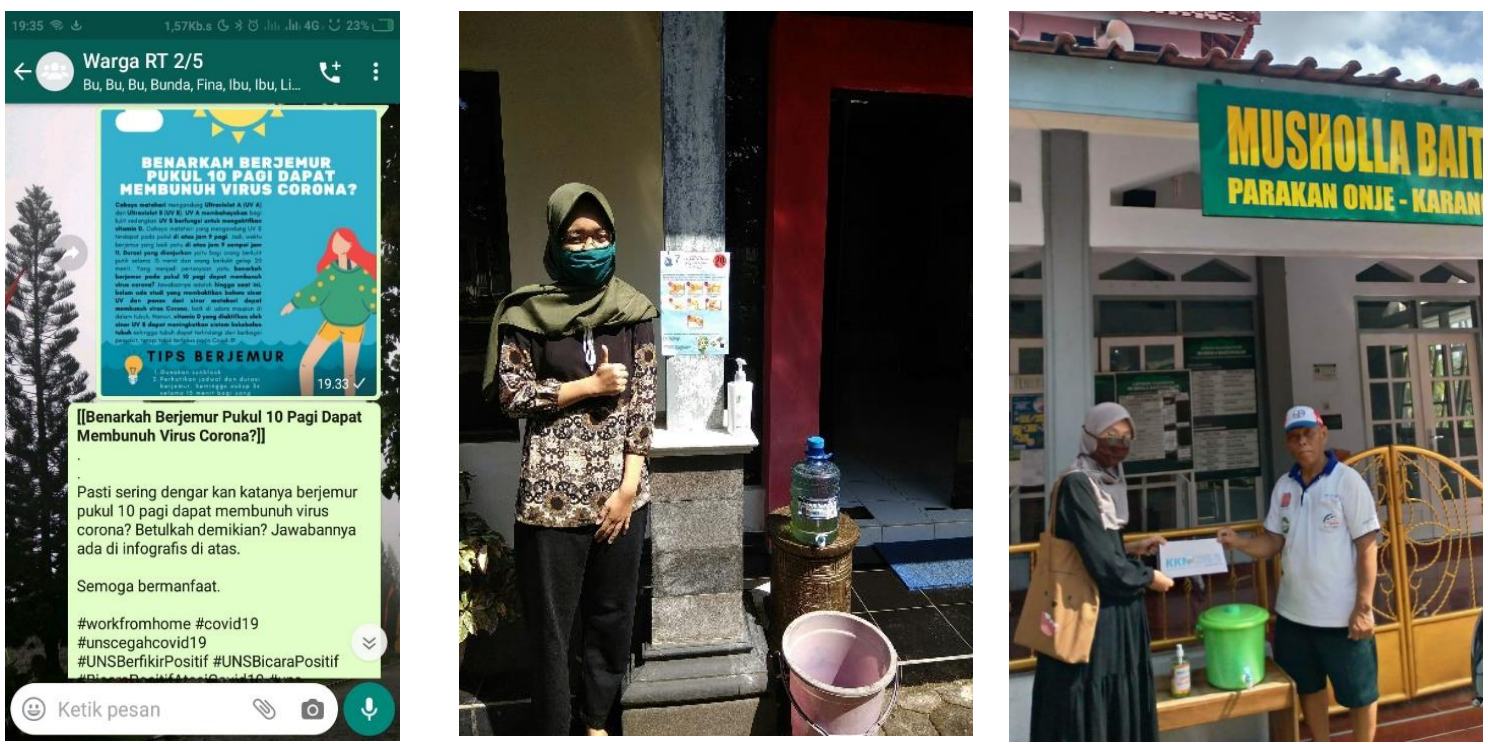

Gambar 1. Kegiatan Sosialisasi Pentingnya PHBS

\section{Pendampingan Kegiatan Belajar di Tengah Covid-19}

Pemerintah Republik Indonesia menerapkan kebijakan ketat yang dapat memutus mata rantai penyebaran Covid-19. Salah satunya adalah social distancing. Bidang pendidikan merupakan salah satu bidang yang dirugikan dengan adanya kebijakan ini. Proses belajar mengajar terganggu dan berjalan tidak efektif. Meskipun pemerintah menganjurkan untuk melaksanakan pembelajaran daring, namun karena ketidaksiapan stakeholder sekolah/madrasah menyebabkan kegiatan belajar melalui daring tidak efektif. Maka dari itu program pendampingan belajar di tengah Covid-19 ini sangatlah dibutuhkan. Diharapkan dengan adanya pendampingan kegiatan belajar ini dapat membantu para siswa yang mengalami kesulitan belajar selama pandemik Covid-19 ini. Kegiatan ini dilakukan oleh Relawan Puput Dwi Lestari di Desa Karangtengah, Kecamatan Baturraden, Kabupaten Banyumas.

Kegiatan belajar dilakukan dua kali dalam seminggu dalam bentuk membantu siswa dalam mengerjakan tugas sekolah dan membantu siswa belajar dalam persiapan Ujian Akhir Semester. Materi khusus yang dipelajari yaitu Matematika dan IPA. Kebanyakan siswa yang mengikuti kegiatan pendampingan ini adalah siswa Sekolah Dasar. Selain melalui tatap muka secara langsung, kegiatan belajar juga dilakukan secara online. Salah satunya dengan mengapload video materi belajar ke youtube sehingga ssiswa dapat mengakses materi tersebut di youtube. Diharapkan dengan adanya program ini dapat membantu para siswa dalam melaksanakan pembelajaran di era Covid-19.
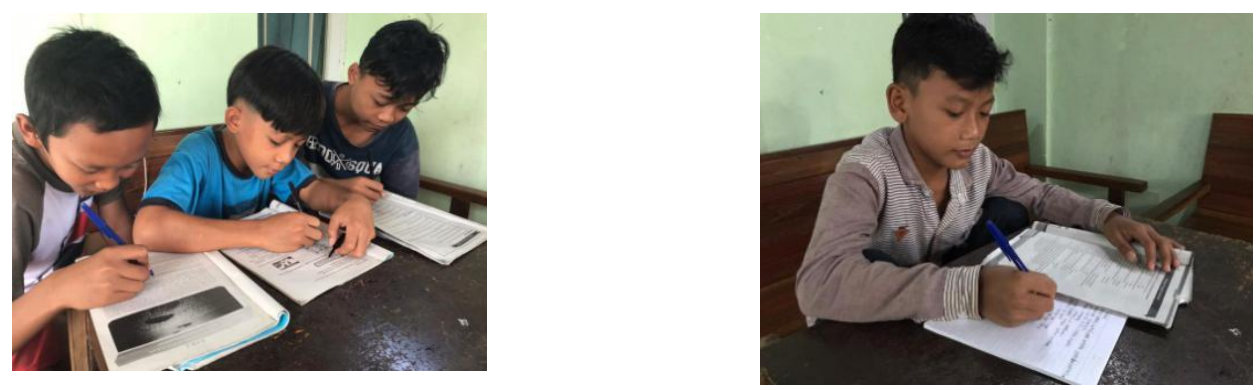

Gambar 2. Kegiatan Pendampingan Kegiatan Belajar di Tengah Covid-19 


\section{Edukasi Era Normal Baru (new normal)}

New normal merupakan kebijakan pemerintah terbaru dan dianggap terbaik untuk menjalani kehidupan ditengan pandemi Covid-19. Setelah memberlakukan pembatasan aktivitas sosial berskala besar, dampaknya tidak hanya pada perubahan gaya hidup masyarakat saja, namun juga ekonomi negara yang berhenti. Inilah mengapa new normal dianggap sebagai jalan keluar terbaik ditengah pandemi Covid19. New normal berarti hidup dan menjalani aktivitas, pekerjaan, dan interaksi dengan orang lain dengan cara yang baru. Dalam menghadapi kehidupan new normal banyak protokol-protokol kesehatan yang perlu dipatuhi guna mencegah penularan Covid-19, maka perlu adanya edukasi mengenai protokol-protokol kesehatan tersebut kepada masyarakat.

Berdasarkan pada kebijakan tersebut maka Relawan Bianca Zain menginisiasikan kegiatan yang mengedukasi masyarakat di Desa Pancurendang terkait protokol-protokol kesehatan yang harus di patuhi pada era new normal. Kegiatan edukasi mengenai new normal ini diawali dengan membuat selebaran mengenai apa itu new normal, bagaimana persiapan kita menghadapi new normal, barang-barang apa saja yang perlu kita siapkan dalam menghadapi new normal, serta bagaimana protokol setelah berpergian. Setelah itu dilakukan edukasi mengenai new normal dengan cara online dan door to door kepada masyarakat setempat. Edukasi mengenai new normal tersebut mendapat respon yang baik dari masyarakat, mengingat pentingnya pemahaman mengenai new. Harapannya setelah program edukasi ini dilakukan, masyarakat lebih berhati-hati ketika beraktivitas diluar rumah dan mencegah diri agar tidak terpapar Covid-19.
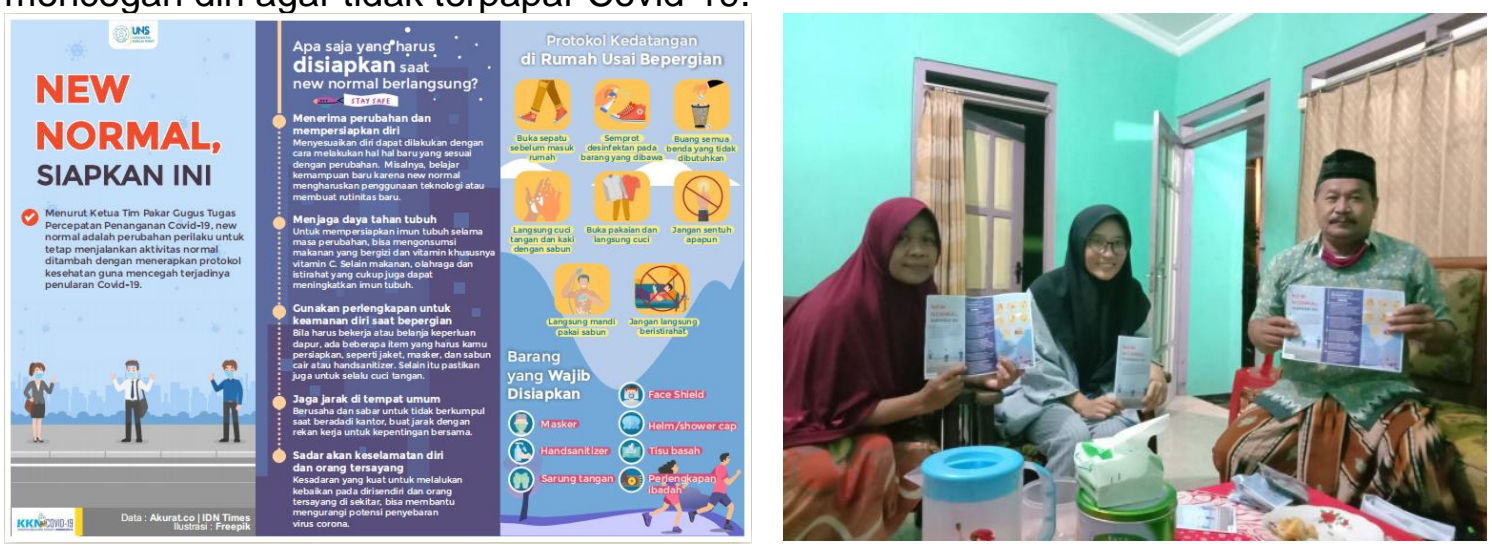

Gambar 3. Kegiatan Edukasi Era Normal Baru (new normal)

\section{Upaya Pengelolaan Stress ditengah Pandemi}

Pandemi Covid-19 yang sedang terjadi saat ini bukan hanya berdampak pada kesehatan fisik saja tetapi dapat berdampak pada kesehatan mental seseorang. Hal ini diperkuat dengan pernyataan WHO yaitu bahwa isolasi, ketakutan, ketidakpastian, kekacauan ekonomi, itu semua menyebabkan tekanan psikologis. Dengan latar belakang tersebut, maka Relawan Sri Pratiwi melakukan sosialisasi terkait tips mencegah stress pada masa pandemi Covid-19 pada masyarakat Kecamatan Karang Lewas Kidul, Kabupaten Banyumas.

Kegiatan ini dilakukan melalui sosial media. Langkah awal yang dilakukan yaitu membuat Mental Health Check-in yang berisi diposisi mana perasaan orang saat ini atau selama pandemic Covid-19 ini. Mental Health Check-in ini semacam pamphlet yang di bagikan melalui WhatsApp Group dan Instagram Story dan dapat disimpan serta diisi lalu dikirimkan kembali kepada relawan jika sudah terisi. Tujuan dari 
kegiatan ini adalah agar relawan dapat mengetahui bagaimana sikap orang lain terutama yang disekitar dalam mengahadapi pandemi ini terutama berkaitan dengan kesehatan mental. Lalu langkah selanjutnya relawan mengirimkan dua poster yang berisi Tips Menjaga Kesehatan Mental serta Tips Mengatasi Stres Selama Masa Pandemi Covid-19. Poster terebut juga dibagikan melalui WhatsApp Group dan WhatsApp Story.
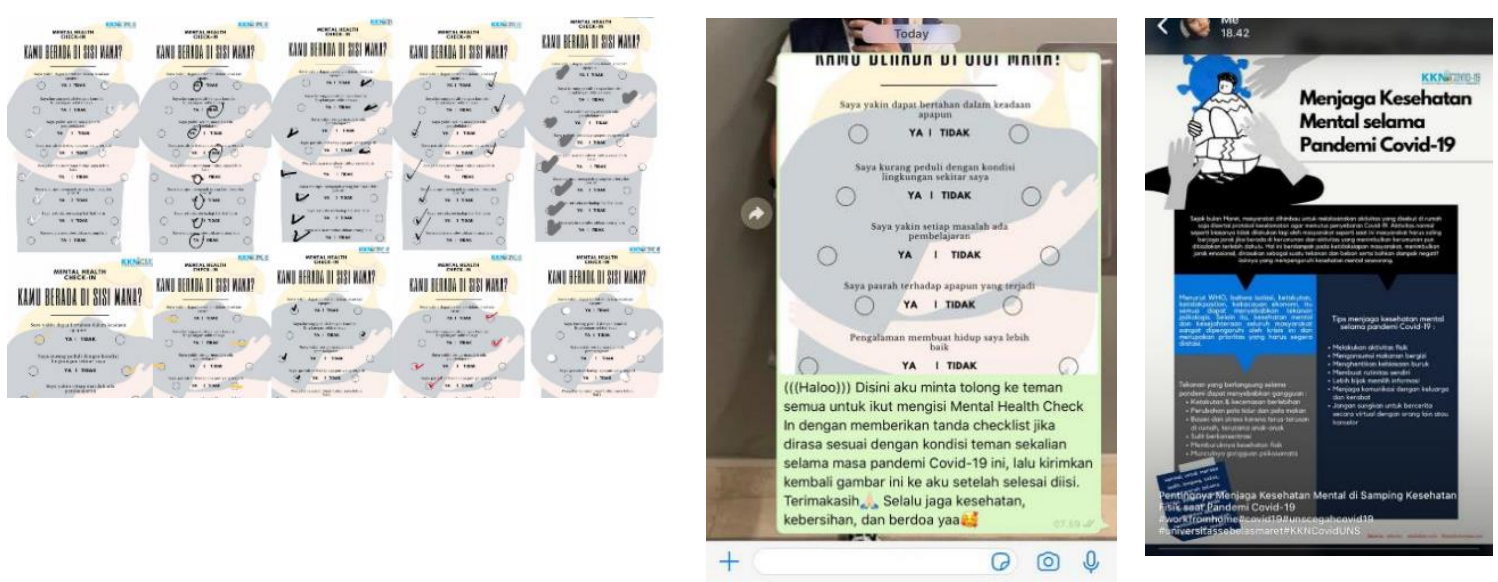

\section{Gambar 4. Upaya Pengelolaan Stress Selama Pandemi}

Kegiatan yang dilakukan oleh relawan Covid-19 ini semua dilakukan di wilayah Kabupaten Banyumas, dan tersebar di 10 desa yang merupakan lingkungan sekitar dari tempat tinggal relawan. Berikut adalah peta tempat pelaksanaan pengabdian masyarakat oleh relawan Covid-19.

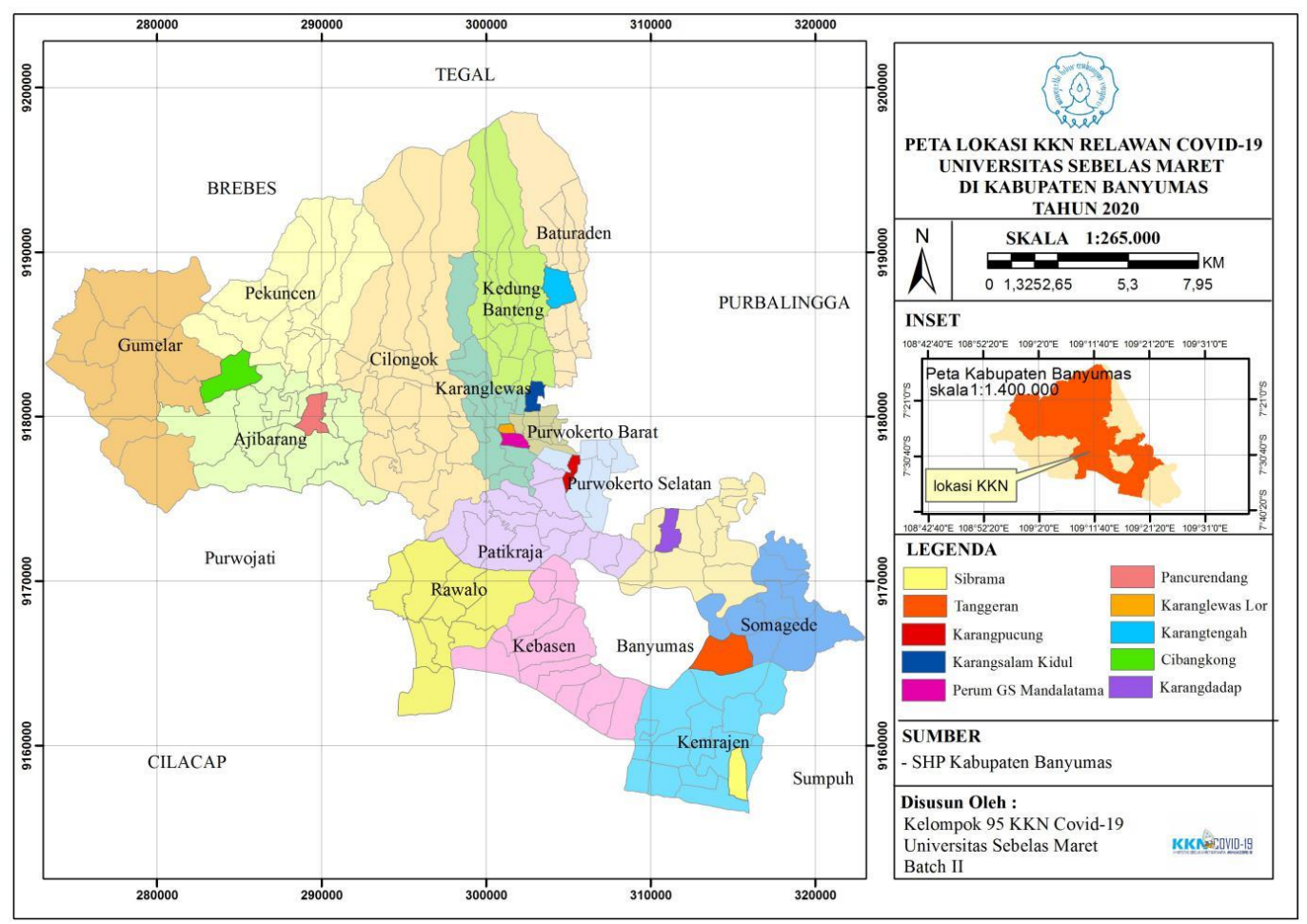

Gambar 5. Peta Lokasi KKN Relawam Covid-19 UNS di Kab. Banyumas tahun 2020 


\section{SIMPULAN}

Kegiatan yang dilakukan oleh relawan Covid-19 ini dapat membuat masyarakat menjadi lebih mengetahui, lebih paham dan sadar akan Virus Covid-19 ini sehingga warga dapat lebih berhati-hati dan terhindar dari penularan dan penyebaran virus Covid-19 ini. Kegiatan yang dilakukan juga memungkinkan adanya kesadaran bersama untuk saling membantu dan peduli sesama dalam menghadapi virus Covid-19 ini. Hal ini terlihat dari masyarakat yang sudah sadar dan mulai menggunakan masker ketika berkegiatan diluar rumah, mencuci tangan dengan sabun dan tahapan yang sesuai, dan mampu untuk menaati protokol kesehatan yang ditetapkan di era normal baru (new normal). Selain itu juga ditengah pandemi ini kegiatan yang dilakukan oleh relawan dapat membantu siswa untuk tetap dapat belajar dirumah dan juga pengelolaan stress yang baik selama menghadapi pandemi ini.

\section{DAFTAR PUSTAKA}

Dewi, W. A. F. (2020). Dampak Covid-19 Terhadap Implementasi Pembelajaran Daring di Sekolah Dasar. Jurnal Ilmu Pendidikan. Research get https://edukatif.org/index.php/edukatif/index

Erwin, A. (2020). Di Purwokerto Timur, Rata-Rata 20 Orang Bandel dan Terjaring Operasi Masker Per Hari. Radar Banyumas. Diunduh dari https://radarbanyumas.co.id/di-purwokerto-timur-rata-rata-20-orang-bandel-danterjaring-operasi-masker-per-hari/

Purwanto, A., Pramono, R., Asbari, M., Hyun, C., Wijayanti, L., Putri, R., \& santoso, priyono. (2020). Studi Eksploratif Dampak Pandemi COVID-19 Terhadap Proses Pembelajaran Online di Sekolah Dasar. EduPsyCouns: Journal of Education, Psychology and Counseling, 2(1), 1-12. Retrieved from https://ummaspul.ejournal.id/Edupsycouns/article/view/397

Taher, A. P. (2020). Pemerintah Perpanjang Status Darurat Bencana Covid-19 Hingga 29 Mei. Tirto.id. Diunduh dari https://tirto.id/pemerintah-perpanjang-statusdarurat-bencana-covid-19-hingga-29-mei-eFJU pada tanggal 16 Juni 2020.

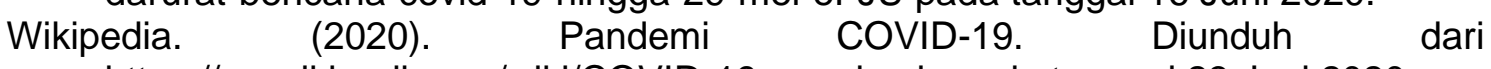
https://en.wikipedia.org/wiki/COVID-19_pandemic pada tanggal 23 Juni 2020. 